\title{
Effect of increasing amounts of supplemental progesterone in a timed artificial insemination protocol on fertility of lactating dairy cows
}

\author{
J. R. Lima, ${ }^{*}$ F. A. Rivera, ${ }^{*}$ C. D. Narciso, ${ }^{*}$ R. Oliveira, ${ }^{*}$ R. C. Chebel, ${ }^{*} \dagger$ and J. E. P. Santos $\ddagger^{1}$ \\ *Veterinary Medicine Teaching and Research Center, University of California-Davis, Tulare 93274 \\ †Department of Veterinary Population Medicine, University of Minnesota, St. Paul 55108 \\ ‡Department of Animal Sciences, University of Florida, Gainesville 32611
}

\section{ABSTRACT}

The objectives were to evaluate the effect of supplemental progesterone during a timed artificial insemination (TAI) protocol on pregnancy per insemination and pregnancy loss. Lactating dairy cows from 2 dairy herds were presynchronized with 2 injections of $\mathrm{PGF}_{2 \alpha}$ $14 \mathrm{~d}$ apart, and cows observed in estrus following the second $\mathrm{PGF}_{2 \alpha}$ injection were inseminated $(\mathrm{n}=1,301)$. Cows not inseminated by $11 \mathrm{~d}$ after the end of the presynchronization were submitted to the TAI protocol (d 0 GnRH, d $7 \mathrm{PGF}_{2 \alpha}$, d 8 estradiol cypionate, and d 10 TAI). On the day of the GnRH of the TAI protocol (study d 0), cows were assigned randomly to receive no exogenous progesterone (control $=432$ ), one controlled internal drug-release (CIDR) insert (CIDR $1=440)$, or 2 CIDR inserts (CIDR2 $=440$ ) containing $1.38 \mathrm{~g}$ of progesterone each from study d 0 to 7 . Blood was sampled on study d 0 before insertion of CIDR for determination of progesterone concentration in plasma, and cows with concentration $<1.0 \mathrm{ng} / \mathrm{mL}$ were classified as low progesterone (LP) and those with concentration $\geq 1.0 \mathrm{ng} /$ $\mathrm{mL}$ were classified as high progesterone (HP). From a subgroup of 240 cows, blood was sampled on study d 3, 7, 17 and 24 and ovaries were examined by ultrasonography on study d 0 and 7 . Pregnancy was diagnosed at $38 \pm 3$ and $66 \pm 3 \mathrm{~d}$ after AI. Data were analyzed including only cows randomly assigned to treatments and excluding cows that were inseminated after the second $\mathrm{PGF}_{2 \alpha}$ injection. The proportion of cows classified as HP at the beginning of the TAI protocol was similar among treatments, but differed between herds. Concentrations of progesterone in plasma during the TAI protocol increased linearly with number of CIDR used, and the increment was $0.9 \mathrm{ng} / \mathrm{mL}$ per CIDR. The proportion of cows with plasma progesterone $\geq 1.0 \mathrm{ng} /$

Received February 16, 2009.

Accepted July 30, 2009.

${ }^{1}$ Corresponding author: jepsantos@ufl.edu
$\mathrm{mL}$ on study d 17 was not affected by treatment, but a greater proportion of control than CIDR-treated cows had asynchronous estrous cycles following the TAI protocol. Treatment with CIDR inserts, however, did not affect pregnancy at $38 \pm 3$ and $66 \pm 3 \mathrm{~d}$ after AI or pregnancy loss.

Key words: dairy cow, progesterone, reproduction, timed artificial insemination

\section{INTRODUCTION}

Poor reproductive efficiency in dairy herds is observed mainly because of decreased pregnancy rates and suboptimal embryo survival (Santos et al., 2004). One of the factors that reduces fertility of dairy cows is anestrus (Santos et al., 2009), which has been associated with reduced pregnancy per AI $(\mathbf{P} / \mathbf{A I})$ and increased risk of pregnancy loss (Santos et al., 2004). Despite the widespread implementation of fixed-time artificial insemination (TAI) protocols for reproductive management of lactating dairy cows, the negative effects of delayed resumption of postpartum ovulation still persists.

Many dairy herds have adopted a reproductive program for first postpartum AI in which cows are presynchronized with 2 injections of $\mathrm{PGF}_{2 \alpha}$ given $14 \mathrm{~d}$ apart, with the last injection given at the end of the voluntary waiting period (Caraviello et al., 2006). Cows that display estrus following the second $\mathrm{PGF}_{2 \alpha}$ injection of the presynchronization are inseminated and those not observed in estrus within the next 2 wk are submitted to a TAI protocol. Because anovular cows are less likely to be in estrus after treatment with $\mathrm{PGF}_{2 \alpha}$ than cyclic cows (Chebel et al., 2006), in the scenario described above, it is reasonable to suggest that an increased proportion of cows submitted to TAI protocols will be anovular. Recent reports indicate that the proportion of anovular cows at the beginning of a TAI protocol ranges from 20 to $40 \%$ (Moreira et al., 2001; Cerri et al., 2004; Santos et al., 2009).

Anovular cows have reduced P/AI following first postpartum AI (Santos et al., 2009) and are more likely 
to experience embryonic/fetal loss (Santos et al., 2004; Stevenson et al., 2006). This may be the consequence of the lack of progesterone priming before the first postpartum ovulation and AI (Folman et al., 1990), which increases the incidence of short luteal cycles following AI (Zollers et al., 1993; Cerri et al., 2009). In addition, growth of the ovulatory follicle under low concentrations of progesterone might also compromise subsequent pregnancy.

Results of studies on the effects of incorporating a controlled internal drug-release (CIDR; Eazi-Breed CIDR insert, Pfizer Animal Health, New York, NY) insert containing progesterone in TAI protocols to increase fertility of lactating dairy cows have been inconsistent, with some reporting improvements (El-Zarkouny et al., 2004; Melendez et al., 2006; Stevenson et al., 2006), and others reporting no effect (El-Zarkouny et al., 2004; Galvão et al., 2004). These inconsistencies could be attributed to differences in genetics and milk yield of cows, type of TAI protocol used, proportion of anovular cows initiating the synchronization protocol, and the resulting low concentration of progesterone in high-producing Holstein cows during treatment with the CIDR (Gümen and Wiltbank, 2005; Cerri et al., 2009).

Although treatment of anovular cows with CIDR results in resumption of cyclicity and a reduced proportion of cows experiencing short luteal cycles following induced ovulation (Chebel et al., 2006; Cerri et al., 2009), the concentrations of circulating progesterone to which cows are exposed when treated with a CIDR insert are subluteal (Cerri et al., 2009). Therefore, one could speculate that the lack of improvement in reproductive outcomes when cows are treated with CIDR, as observed in some studies, could be associated with the inability of these inserts to increase progesterone to luteal concentrations.

Therefore, we hypothesized that increasing the concentrations of circulating progesterone by using CIDR inserts during a TAI protocol would improve fertility of dairy cows not observed in estrus after presynchronization with $\mathrm{PGF}_{2 \alpha}$. Furthermore, we hypothesized that the benefit from additional supplementation with progesterone would be greater in cows initiating the TAI protocol without an active corpus luteum (CL) when treated with 2 CIDR inserts. The objectives of this study were to evaluate the effect of treating lactating dairy cows with increasing amounts of progesterone using 1 or 2 CIDR inserts during a TAI protocol on concentrations of progesterone in plasma, synchrony of the estrous cycle, and fertility.

\section{MATERIALS AND METHODS}

This study was approved by the Animal Care and Use Committee of the University of California, Davis.

\section{Animals and Treatments}

Holstein cows $(\mathrm{n}=2,613)$ from 2 commercial dairy herds ( $\mathrm{A}$ and $\mathrm{B}$ ) located in California were enrolled in this study. In dairy A, cows were housed in open lots, whereas in dairy B they were housed in free-stall barns. Cows had their estrous cycles presynchronized with 2 s.c. injections of $\mathrm{PGF}_{2 \alpha}(25 \mathrm{mg}, 5 \mathrm{~mL}$ of Lutalyse Sterile Solution; Pfizer Animal Health) given $14 \mathrm{~d}$ apart, with the injections given at $36 \pm 3$ and $50 \pm 3$ DIM. In the $11 \mathrm{~d}$ that followed the second $\mathrm{PGF}_{2 \alpha}$ injection of the presynchronization, cows that were observed in estrus were inseminated $(\mathrm{n}=1,301)$, and cows not inseminated were submitted to a TAI protocol (Figure 1). The beginning of the TAI protocol was designated as $\mathrm{d}$ 0, and the protocol consisted of an i.m. injection of GnRH (100 $\mu \mathrm{g}$ of Cystorelin, Merial Ltd., Duluth, $\mathrm{GA}$ ) on d 0 , and an s.c. injection of $25 \mathrm{mg}$ of $\mathrm{PGF}_{2 \alpha}$ on d 7, and an i.m. injection of $1 \mathrm{mg}$ of estradiol cypionate (ECP; Pfizer Animal Health) on d 8, and TAI on d 10. On study d 0, cows were randomly assigned to receive no additional treatment (control, $\mathrm{n}=432$ ), 1 CIDR insert containing $1.38 \mathrm{~g}$ of progesterone from d 0 to 7 (CIDR1, $\mathrm{n}=440$ ), or 2 CIDR inserts from d 0 to 7 (CIDR2, $\mathrm{n}=440$ ).

\section{Detection of Estrus and AI}

Cows were observed for estrus during the morning based on removal of tail chalk, and cows in estrus or those with removed tail chalk were inseminated in the same morning. In dairy A, insemination was performed by 2 technicians, whereas in dairy $\mathrm{B}, \mathrm{AI}$ was performed by 3 technicians.

\section{BCS and Milk Yield}

Cows were scored for body condition $(1=$ emaciated, $5=$ obese) according to Ferguson et al. (1994) on study d 0 . For purpose of statistical analysis, cows were classified according to BCS as low (BCS $\leq 2.75)$ or moderate (BCS $\geq 3.00$; Santos et al., 2009).

Cows were milked twice daily in dairy A and thrice daily in dairy $\mathrm{B}$, and milk yields were measured monthly for individual cows in the first 3 mo postpartum by the California DHI. The first monthly test occurred between 6 and 35 DIM, the second test between 36 and 


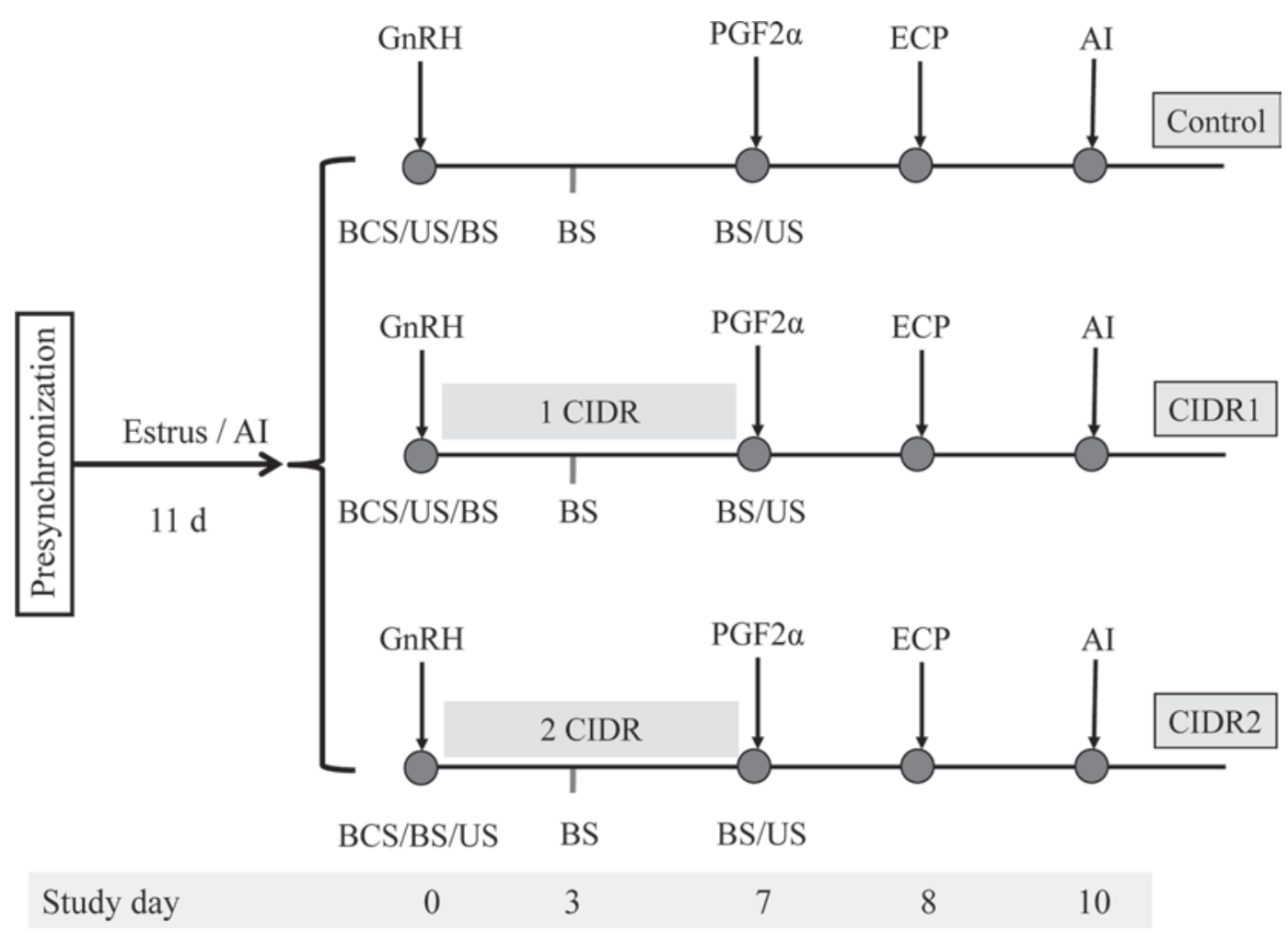

Figure 1. Timeline of activities during the study. BS = blood samples for analysis of progesterone concentration; CIDR $=$ controlled internal drug-release (CIDR) insert containing $1.38 \mathrm{~g}$ of progesterone; $\mathrm{ECP}=$ injection of $1.0 \mathrm{mg}$ of estradiol cypionate; GnRH $=$ injection of 100 $\mu \mathrm{g}$ of gonadorelin diacetate tetrahydrate; $\mathrm{PGF}_{2 \alpha}=$ injection of $25 \mathrm{mg}$ of dinoprost as tromethamine salt; US $=$ ultrasonography of the ovaries. Additional blood samples were also collected on study d 17 and 24 for analysis of progesterone concentration in plasma.

65 DIM, and the third test between 66 and 95 DIM. The average milk production in the first 95 DIM was used in the statistical analysis.

\section{Blood Sampling, Progesterone Assay, and Characterization of Progesterone Status, Late Ovulation, and Early Luteal Regression}

Approximately $7 \mathrm{~mL}$ of blood was collected by puncture of the coccygeal artery or vein using evacuated tubes with $\mathrm{K}_{2}$ EDTA (Vacutainer, Becton Dickinson, Franklin Lakes, NJ). Samples were placed in ice upon collection and were transported to the laboratory within $5 \mathrm{~h}$. Blood samples were centrifuged and plasma separated and frozen at $-25^{\circ} \mathrm{C}$ and later analyzed for progesterone concentration by a validated ELISA (Cerri et al., 2004). Sensitivity of the assay was $0.05 \mathrm{ng} / \mathrm{mL}$ and the intra- and interassay CV were 5.0 and $11.7 \%$, respectively.

Blood was collected from all cows submitted to the TAI protocol on study d 0 to determine progesterone concentrations. Cows with progesterone concentration in plasma $<1 \mathrm{ng} / \mathrm{mL}$ on study d 0 were classified as low progesterone $(\mathbf{L P})$, whereas cows with concentration $\geq 1 \mathrm{ng} / \mathrm{mL}$ were classified as high progesterone (HP).
From a subgroup of cows (control $=74$, CIDR $1=77$, CIDR2 $=83$ ) blood was also sampled on study d 3,7 , 17 , and 24 , the latter 2 sampling days corresponding to 7 and $14 \mathrm{~d}$ after TAI.

A functional CL was expected to be present on d 7 and 14 after TAI (study d 17 and 24) in cows that responded to the ovulation synchronization protocol. Therefore, cows on d 7 and 14 after TAI were expected to be in diestrus and have concentrations of progesterone in plasma $\geq 1 \mathrm{ng} / \mathrm{mL}$. Cows with concentrations of progesterone in plasma $<1.0 \mathrm{ng} / \mathrm{mL}$ and $\geq 1.0 \mathrm{ng} /$ $\mathrm{mL}$ on study d 17 and 24 , respectively, were considered to have experienced delayed ovulation following the TAI protocol, whereas cows that had concentrations of progesterone in plasma $\geq 1.0 \mathrm{ng} / \mathrm{mL}$ and $<1.0 \mathrm{ng} /$ $\mathrm{mL}$ on study d 17 and 24 , respectively, were considered to have had premature luteolysis. Cows experiencing either delayed ovulation or premature luteolysis were considered to have asynchronous estrous cycle.

\section{Ovarian Ultrasonography}

Ultrasonography of the ovaries was performed in the same subgroup of cows from which additional blood samples were collected $(\mathrm{n}=234)$. Cows were examined 
with an ultrasound machine equipped with a $7.5-\mathrm{MHz}$ linear transducer (Sonovet 2000, Universal Medical System, Bedford Hills, NY) on the day of the injection of $\mathrm{GnRH}$ and on the day of the $\mathrm{PGF}_{2 \alpha}$ injection of the TAI protocol. Size and position of the CL and follicles $>9 \mathrm{~mm}$ in diameter were recorded on ovarian maps. Cows with a follicle $>9 \mathrm{~mm}$ on the day of $\mathrm{GnRH}$ injection of the TAI protocol and with a newly formed CL on the day of the $\mathrm{PGF}_{2 \alpha}$ injection of the TAI protocol on the same ovary were considered to have ovulated in response to the GnRH injection of the TAI protocol.

\section{Pregnancy Diagnosis and Calculation of Reproductive Outcomes}

Pregnancy was diagnosed by palpation of the uterus and its contents per rectum at $38 \pm 3 \mathrm{~d}$ after AI. Cows diagnosed pregnant on d $38 \pm 3$ after AI were re-examined by palpation per rectum on d $66 \pm 3$ after AI. Cows that displayed estrus and were re-inseminated before the pregnancy diagnosis on d $38 \pm 3$ after AI were considered to be nonpregnant to the first AI, whereas cows pregnant at $38 \pm 3 \mathrm{~d}$ after AI that were re-inseminated before d $66 \pm 3$ after AI were considered to have had pregnancy loss.

Pregnancy per AI was calculated by dividing the number of cows diagnosed pregnant at $38 \pm 3$ or 66 $\pm 3 \mathrm{~d}$ after AI by the number of cows receiving AI. Pregnancy per AI was also calculated for those cows inseminated after estrus following the second injection of $\mathrm{PGF}_{2 \alpha}$ of the presynchronization protocol and before study d 0 . Proportion of cows having pregnancy loss was calculated as the number of cows that lost pregnancy between $38 \pm 3$ and $66 \pm 3 \mathrm{~d}$ after AI divided by the number of cows diagnosed pregnant at $38 \pm 3$ d after AI.

\section{Study Design and Statistical Analyses}

The study was designed as a completely randomized block design of 3 treatments within dairy for cows not inseminated before study d 0 . A previous study reported that cows treated with a single CIDR containing $1.9 \mathrm{~g}$ of progesterone had an increase in $\mathrm{P} / \mathrm{AI}$ of 8.5 percentage units (Melendez et al., 2006). The sample size was calculated based on the data from Melendez et al. (2006) and 425 cows were initially planned per treatment to provide enough replicates to detect statistical significance with a 7 -percentage-unit improvement in $\mathrm{P} / \mathrm{AI}$ for cows receiving supplemental progesterone, when $\mathrm{P} /$ AI ranges from 30 to $40 \%$ ( $\alpha=0.05$ and $\beta=0.80$; onetailed test). Furthermore, the number of experimental units was expected to provide enough pregnant cows at $38 \pm 3 \mathrm{~d}$ after TAI to detect statistical significance with a 8-percentage-unit difference in pregnancy loss between treatments, when pregnancy loss between 38 \pm 3 and $66 \pm 3 \mathrm{~d}$ of gestation ranges from 10 to $22 \%$ $(\alpha=0.05 ; \beta=0.80)$.

Dichotomous outcomes were analyzed by logistic regression using the LOGISTIC procedure of SAS (SAS/STAT version 9.1, SAS Institute Inc., Cary, NC). The logistic regression models removed variables by a backward elimination based on the Wald's statistics criterion if $P>0.15$.

Pregnancy per AI and pregnancy loss were analyzed by statistical models that included treatment (control, CIDR1, and CIDR2), parity (primiparous and multiparous), dairy (A and B), BCS (low and moderate), circulating progesterone concentration on d 0 (LP and HP), and average milk yield on the first 95 DIM, and interactions of significant covariates with treatment. The effect of the interaction between treatment and dairy on pregnancy loss was not evaluated because of quasi-complete separation of data points.

Models used to evaluate the proportion of cows that had delayed ovulation, premature luteolysis, and asynchronous estrous cycle included treatment, parity, dairy, BCS, circulating progesterone concentration on d 0 , average milk yield, and interactions of significant covariates with treatment. In the analysis of premature luteolysis, parity and circulating progesterone concentration on d 0 were not included as covariates because of quasi-complete separation of data points.

The proportion of cows that ovulated in response to the GnRH injection of the TAI protocol and the proportion of cows that had a CL on the day of $\mathrm{PGF}_{2 \alpha}$ injection were analyzed with models that included the effects of treatment, parity, dairy, BCS, circulating progesterone concentration on $\mathrm{d} 0$, and interactions of significant covariates with treatment. Pregnancy per AI of cows examined for ovulation in response to the GnRH injection of the TAI protocol was analyzed with a model that included the effects of treatment, parity, dairy, BCS, ovulation in response to the $\mathrm{GnRH}$ injection (yes and no), and interactions of covariates with treatment.

Number of CL and size of the largest follicle on the day of the $\mathrm{PGF}_{2 \alpha}$ injection of the TAI protocol were analyzed by ANOVA using the GLM procedure of SAS, with a model that included treatment, circulating progesterone concentration on d 0 , average milk yield, and interactions of significant covariates with treatment. For analysis of size of the largest follicle on the day of the $\mathrm{PGF}_{2 \alpha}$ injection, ovulation to the $\mathrm{GnRH}$ injection of the TAI protocol was also included in the statistical model.

Concentration of progesterone in plasma on study $\mathrm{d}$ 0 was analyzed by ANOVA using the GLM procedure 
of SAS, with a model that included treatment, parity, dairy, BCS, average milk yield, and interactions of treatment with parity, dairy and BCS. Progesterone concentrations on $\mathrm{d} 3$ and 7 of the timed AI protocol were analyzed by ANOVA for repeated measures using the MIXED procedure of SAS, with a model that included treatment, parity, dairy, progesterone concentration in plasma on d 0, BCS, average milk yield, day of blood sampling, interaction between treatment and day of sampling, and interactions of treatment with parity, dairy, and BCS. Orthogonal polynomials were performed to determine linear and quadratic effects of treatment on progesterone concentrations. Progesterone concentrations on study d 17 and 24 were analyzed by ANOVA using the GLM procedure of SAS, with a model that included treatment, parity, dairy, BCS, pregnancy status at $38 \pm 3$, average milk yield, and interactions of treatment with parity, dairy and BCS. For analysis of progesterone concentration on d 24, concentration on d 17 was included in the statistical model as a covariate.

\section{RESULTS}

The proportion of cows inseminated after estrus following the second $\mathrm{PGF}_{2 \alpha}$ injection of the presynchronization protocol was $49.8 \%$. Dairy had no effect on the proportion of cows detected in estrus, but more $(P$ $<0.01$ ) multiparous than primiparous cows (53.0 vs. 41.1\%) were inseminated following the second $\mathrm{PGF}_{2 \alpha}$ of the presynchronization protocol. A tendency for an interaction $(P=0.10)$ between dairy and parity was observed for cows detected in estrus as the proportion of primiparous cows inseminated after estrus was similar between dairies A and B (40.3 vs. $41.2 \%)$, but more multiparous cows were inseminated after estrus on dairy A than on dairy B (59.8 vs. $51.5 \%$ ). The average DIM at first postpartum AI was $55.9 \pm 0.1$ for cows inseminated after detected estrus following the second $\mathrm{PGF}_{2 \alpha}$ of the presynchronization protocol, and $71.8 \pm$ 0.1 for cows submitted to the TAI protocol.

Milk yield was similar among treatments $(40.1 \pm 0.2$ $\mathrm{kg} / \mathrm{d})$ but differed $(P<0.01)$ between dairies (dairy A $=39.7 \pm 0.3$, dairy $\mathrm{B}=37.7 \pm 0.2 \mathrm{~kg} / \mathrm{d}$ ) and according to parity (primiparous $=33.4 \pm 0.3$, multiparous $=$ $44.0 \pm 0.2 \mathrm{~kg} / \mathrm{d})$. Body condition score at the beginning of the TAI protocol was not different among treatments and averaged $2.87 \pm 0.01$, but cows on dairy A had decreased $(P<0.01)$ BCS compared with those on dairy B ( $2.80 \pm 0.03$ vs. $2.89 \pm 0.01)$.

The proportion of cows that retained the CIDR inserts during the 7-d treatment period was similar for CIDR1 (95.9\%) and CIDR2 (96.4\%) cows. Of the 16 CIDR2 cows that lost CIDR, 14 lost 1 insert and 2 cows lost both inserts.

\section{Progesterone Status at the Beginning of the TAI Protocol}

The proportion of HP cows at the beginning of the TAI protocol did not differ among treatments (control $=79.8 \%$, CIDR $1=82.2 \%$, CIDR $2=80.7 \%)$. The prevalence of HP cows, however, was affected $(P<0.01)$ by dairy $(\mathrm{A}=88.9 \%, \mathrm{~B}=79.4 \%)$, parity (primiparous $=$ $74.2 \%$, multiparous $=84.0 \%)$, and BCS (low $=77.4 \%$, moderate $=84.8 \%$ ).

\section{Ovarian Responses to Treatments}

Treatment with 1 or 2 CIDR did not affect the proportion of cows ovulating in response to the $\mathrm{GnRH}$ injection, but it was affected $(P=0.02)$ by BCS, and cows classified as thin had an increased incidence of ovulation when compared with cows with moderate BCS, 51.1 versus 35.8, respectively (Table 1 ). Presence of CL $(P<0.01)$ and number of CL $(P=0.04)$ on the day of the $\mathrm{PGF}_{2 \alpha}$ injection of the TAI protocol, however, were affected by treatment. Although there was no difference in proportion of control and CIDR2 cows that had a CL on the day of $\mathrm{PGF}_{2 \alpha}$ injection, CIDR1 cows were less likely to have a CL than control $(P<$ $0.01)$ and CIDR2 $(P=0.03)$ cows. Similarly, there was no difference in number of CL on the day of $\mathrm{PGF}_{2 \alpha}$ injection between control and CIDR2 cows, but CIDR1 cows had $(P=0.01)$ and tended to have $(P=0.07)$ fewer CL than control and CIDR2 cows, respectively.

The diameter of the largest follicle on the day of $\mathrm{PGF}_{2 \alpha}$ injection of the TAI protocol was not affected by treatment, but cows that ovulated in response to the GnRH injection of the TAI protocol had smaller follicles $(P=0.03)$ than cows that did not ovulate $(16.6$ \pm 0.56 vs. $18.1 \pm 0.52 \mathrm{~mm}$ ). The interaction between treatment and ovulation in response to the GnRH injection tended $(P=0.09)$ to affect follicle diameter (Figure 2), because, among control and CIDR1 cows, those that ovulated tended to have $(P=0.08)$ and had $(P=0.02)$ smaller follicles than those that did not ovulate, respectively, but among CIDR2 cows, ovulation to the GnRH at the beginning of the TAI protocol had no effect on diameter of the largest follicle at the $\mathrm{PGF}_{2 \alpha}$ of the protocol.

\section{Progesterone Concentration During and After the TAI Protocol}

Among cows from which blood samples were collected on d $3,7,17$, and 24 , progesterone concentration on d 0 did not $(P=0.94)$ differ among treatments and averaged $4.20 \pm 0.35 \mathrm{ng} / \mathrm{mL}$. On d 0 , primiparous cows had greater $(P=0.03)$ progesterone concentrations than 


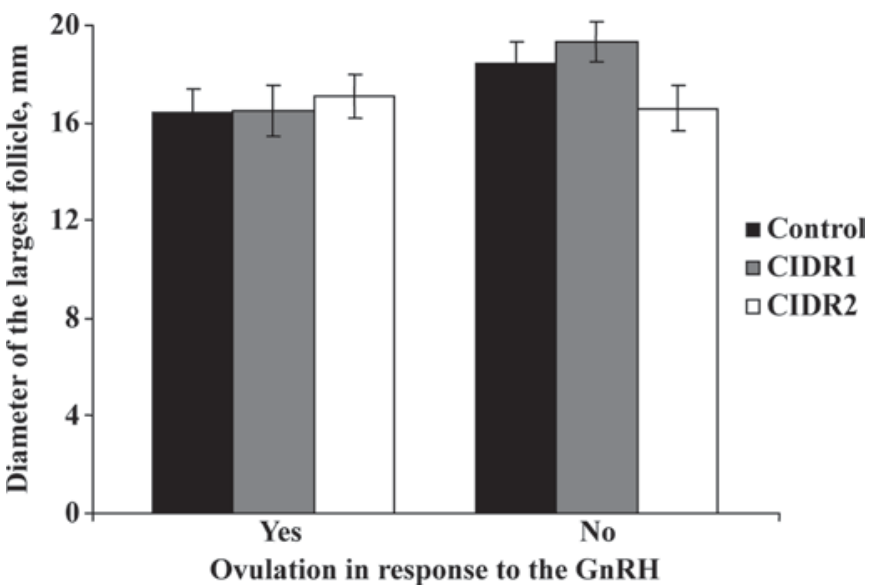

Figure 2. Effect of the interaction between treatment and ovulation to the GnRH injection of the timed AI protocol on the diameter of the largest follicle on the day of $\mathrm{PGF}_{2 \alpha}$ injection of the timed $\mathrm{AI}$ protocol. Control (yes, $\mathrm{n}=40 ;$ no, $\mathrm{n}=34$ ) = no exogenous progesterone during the timed AI protocol: CIDR1 (yes, $\mathrm{n}=29 ;$ no, $\mathrm{n}=48$ ) $=$ 1 controlled internal drug-release (CIDR) insert containing $1.38 \mathrm{~g}$ of progesterone from d 0 to 7 ; CIDR2 (yes, $\mathrm{n}=36$; no, $\mathrm{n}=47$ ) $=2$ CIDR inserts containing $1.38 \mathrm{~g}$ of progesterone from d 0 to 7 . Effect of treatment $(P=0.20)$, ovulation $(P=0.04)$, and the interaction between treatment and ovulation $(P=0.09)$.

multiparous cows (4.82 \pm 0.44 vs. $3.68 \pm 0.24 \mathrm{ng} / \mathrm{mL})$, and cows with moderate BCS had greater $(P<0.01)$ progesterone concentrations than those with low BCS $(5.11 \pm 0.33$ vs. $3.39 \pm 0.27 \mathrm{ng} / \mathrm{mL})$.

Progesterone concentrations during the TAI protocol increased linearly $(P<0.01)$ with increased number of CIDR administered to cows (control $=4.14 \pm 0.27$, CIDR $1=5.00 \pm 0.26$, CIDR2 $=5.90 \pm 0.26 \mathrm{ng} / \mathrm{mL})$. Concentrations of progesterone increased $(P<0.01)$ from $\mathrm{d} 3$ to 7 , but no interaction $(P=0.11)$ between treatment and day of the TAI protocol was observed for progesterone concentrations (Figure 3).

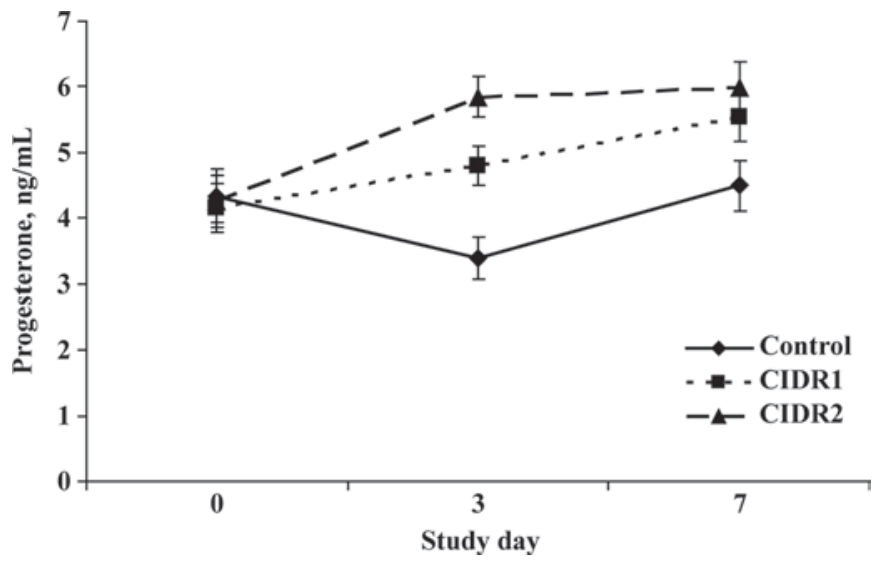

Figure 3. Effect of treatment on progesterone concentrations during the timed AI protocol. Cows not observed in estrus after the presynchronization (2 injections of $\mathrm{PGF}_{2 \alpha} 14 \mathrm{~d}$ apart) received the timed AI $\left(\mathrm{GnRH} d \mathrm{~d}, \mathrm{PGF}_{2 \alpha} \mathrm{d}\right.$ 7, estradiol cypionate $\mathrm{d} 8$, and timed AI d 10) protocols. Control $(n=79)=$ no exogenous progesterone during the timed AI protocol; CIDR1 $(\mathrm{n}=80)=1$ controlled internal drugrelease (CIDR) insert containing $1.38 \mathrm{~g}$ of progesterone from $\mathrm{d} 0$ to 7 of the timed AI protocol; CIDR2 $(\mathrm{n}=85)=2$ CIDR inserts from $\mathrm{d} 0$ to 7 of the timed AI protocol. Effect of treatment $(P<0.01)$, day $(P$ $<0.01)$, and the interaction between treatment and day $(P=0.11)$. A linear effect $(P<0.01)$ of treatment was observed.

Concentrations of progesterone on study d 17 and 24 were not affected by treatment (Figure 4). Similarly, progesterone concentration on d 0 did not affect progesterone concentration on d 17 or 24. Primiparous cows had $(P=0.05)$ and tended $(P=0.07)$ to have greater progesterone concentrations than multiparous cows on $\mathrm{d} 17(4.04 \pm 0.35$ vs. $3.30 \pm 0.21 \mathrm{ng} / \mathrm{mL})$ and $24(6.00 \pm 0.39$ vs. $5.26 \pm 0.24 \mathrm{ng} / \mathrm{mL})$, respectively. Cows with moderate BCS tended to $(P=0.08)$ and had $(P=0.02)$ greater progesterone concentrations than cows with low BCS on d $17(3.91 \pm 0.29$ vs. 3.44 $\pm 0.23 \mathrm{ng} / \mathrm{mL})$ and $24(5.97 \pm 0.31$ vs. $5.28 \pm 0.26$

Table 1. Effect of treatment on ovarian responses [\% (no./no.)] of dairy cows

\begin{tabular}{|c|c|c|c|c|}
\hline \multirow[b]{2}{*}{ Response } & \multicolumn{3}{|c|}{ Treatment $^{1}$} & \multirow[b]{2}{*}{$P$-value } \\
\hline & Control & CIDR1 & CIDR2 & \\
\hline \multirow{2}{*}{$\begin{array}{l}\text { Ovulation to first } \mathrm{GnRH}^{2} \\
\text { Corpus luteum at } \mathrm{PGF}_{2 \alpha} \\
\% \text { of cows } \\
\text { Number }( \pm \mathrm{SEM})\end{array}$} & $54.1(40 / 74)$ & $37.7(29 / 77)$ & $43.4(36 / 83)$ & 0.18 \\
\hline & $\begin{array}{l}90.5(67 / 74)^{\mathrm{a}} \\
1.2 \pm 0.11^{\mathrm{b}}\end{array}$ & $\begin{aligned} 77.9(60 / 77)^{\mathrm{b}} & \\
0.7 & \pm 0.17^{\mathrm{a}, \mathrm{A}}\end{aligned}$ & $\begin{array}{c}84.3(70 / 83)^{\mathrm{b}} \\
1.1 \pm 0.12^{\mathrm{B}}\end{array}$ & $\begin{array}{l}0.02 \\
0.04\end{array}$ \\
\hline \multicolumn{5}{|c|}{${ }^{\mathrm{a}, \mathrm{b}}$ Values within row having different superscript letters differ $(P<0.05)$. } \\
\hline \multicolumn{5}{|c|}{$\begin{array}{l}{ }^{1} \text { Cows not observed in estrus after the presynchronization }\left(2 \text { injections of } \mathrm{PGF}_{2 \alpha} 14 \mathrm{~d} \text { apart }\right) \text { received timed } \\
\mathrm{AI}\left(\mathrm{GnRH} \mathrm{d} 0, \mathrm{PGF}_{2 \alpha} \mathrm{d} 7 \text {, estradiol cypionate } \mathrm{d} 8 \text {, and timed } \mathrm{AI} \mathrm{d} 10\right) \text { protocols. Control = no exogenous } \\
\text { progesterone during the timed AI protocol; CIDR } 1=1 \text { controlled internal drug-release (CIDR) insert contain- } \\
\text { ing } 1.38 \mathrm{~g} \text { of progesterone from d } 0 \text { to } 7 \text { of the timed AI protocol; CIDR } 2=2 \text { CIDR inserts from d } 0 \text { to } 7 \text { of } \\
\text { the timed AI protocol. }\end{array}$} \\
\hline \multicolumn{5}{|c|}{$\begin{array}{l}{ }^{2} \text { Cows with a follicle }>9 \mathrm{~mm} \text { on the day of the } \mathrm{GnRH} \text { injection of the timed AI protocol and with a newly } \\
\text { formed corpus luteum present on the same ovary } 7 \mathrm{~d} \text { later. }\end{array}$} \\
\hline
\end{tabular}




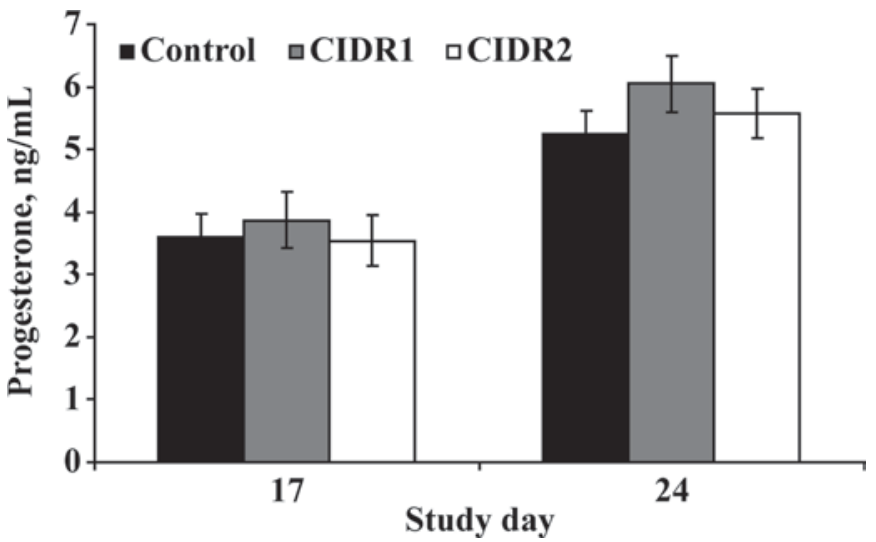

Figure 4. Effect of treatment on concentrations of progesterone on study d 17 and 24, which correspond to d 7 and 14 after timed AI. Cows not observed in estrus after the presynchronization (2 injections of $\mathrm{PGF}_{2 \alpha} 14 \mathrm{~d}$ apart) received the timed $\mathrm{AI}\left(\mathrm{GnRH} d \mathrm{~d}, \mathrm{PGF}_{2 \alpha} \mathrm{d} 7\right.$, estradiol cypionate $\mathrm{d} 8$, and timed AI d 10) protocols. Control $(\mathrm{n}=78)$ $=$ no exogenous progesterone during the timed AI protocol; CIDR1 $(\mathrm{n}$ $=79)=1$ controlled internal drug-release (CIDR) insert containing $1.38 \mathrm{~g}$ of progesterone from d 0 to 7 of the timed AI protocol; CIDR2 $(\mathrm{n}=85)=2$ CIDR inserts from d 0 to 7 of the timed AI protocol. Treatment had no effect on concentrations of progesterone on study d $17(P=0.82)$ and $24(P=0.37)$.

$\mathrm{ng} / \mathrm{mL})$, respectively. Pregnancy status at $38 \pm 3 \mathrm{~d}$ was associated with progesterone concentrations on $\mathrm{d}$ $17(P=0.03)$ and $24(P<0.01)$, and cows diagnosed pregnant had greater progesterone concentrations than cows not diagnosed pregnant on both days, $3.95 \pm 0.25$ versus $3.39 \pm 0.26 \mathrm{ng} / \mathrm{mL}$ and $6.04 \pm 0.28$ versus 5.21 $\pm 0.29 \mathrm{ng} / \mathrm{mL}$, respectively.

Treatment did not affect the proportion of cows with progesterone $\geq 1.0 \mathrm{ng} / \mathrm{mL}$ on d 17 (Table 2). Delayed ovulation was not affected by treatment, but inserting 1 or 2 CIDR tended $(P=0.07)$ to reduce the propor- tion of cows that experienced premature luteolysis after AI. Last, the incidence of asynchronous estrous cycle was reduced $(P=0.03)$ by treatment with 1 or 2 CIDR inserts during the TAI protocol. Five cows (2 CIDR1 and 3 CIDR2) did not ovulate and had LP in both $\mathrm{d}$ 17 and 24 .

\section{Pregnancy/Al and Pregnancy Loss}

Pregnancy per AI did not differ between dairies for cows inseminated after estrus following the presynchronization protocol and it averaged $40.9 \%$ on d $38 \pm 3$ after AI. On d $66 \pm 3$ after AI, however, cows in dairy A tended $(P=0.06)$ to have decreased $\mathrm{P} / \mathrm{AI}$ compared with dairy B (31.9 vs. $39.3 \%)$, because cows in dairy A were more $(P<0.01)$ likely to lose their pregnancy than those in dairy B (13.8 vs. $6.2 \%)$. For cows randomly assigned to treatments, dairy had no effect on $\mathrm{P} / \mathrm{AI}$.

Treatment did not affect $\mathrm{P} / \mathrm{AI}$ at $38 \pm 3$ or $66 \pm 3 \mathrm{~d}$ after TAI (Table 3). On d 38 after AI, 35.9, 39.1, and $37.1 \%$ of the cows were pregnant in control, CIDR1, and CIDR2, respectively. Interestingly, supplementation using 1 or 2 CIDR was not more effective in cows that were classified as LP compared with those that were classified as HP. Cows classified as LP, however, tended to have decreased $(P<0.07) \mathrm{P} / \mathrm{AI}$ at $38 \pm 3$ and $66 \pm 3 \mathrm{~d}$ after AI compared with HP cows. Cows with low BCS at enrollment had decreased $(P<0.01)$ $\mathrm{P} / \mathrm{AI}$ at $38 \pm 3(32.7$ vs. $42.5 \%)$ and $66 \pm 3$ (30.7 vs. $38.1 \%$ ) d after AI compared with those with moderate $\mathrm{BCS}$, but no interaction between treatment and BCS was observed. Similarly, no interaction between treatment and dairy was observed for P/AI.

Pregnancy loss did not differ between dairies. Treatment, progesterone concentration on d 0 , parity, and

Table 2. Effect of treatment on estrous cycle synchronization [\% (no./no.)] following timed AI

\begin{tabular}{|c|c|c|c|c|}
\hline \multirow[b]{2}{*}{ Response } & \multicolumn{3}{|c|}{ Treatment $^{1}$} & \multirow[b]{2}{*}{$P$-value } \\
\hline & Control & CIDR1 & CIDR2 & \\
\hline $\begin{array}{l}\mathrm{P} 4 \geq 1.0 \mathrm{ng} / \mathrm{mL} 7 \mathrm{~d} \text { after } \mathrm{AI}^{2} \\
\text { Delayed ovulation } \\
\text { Premature luteolysis } \\
\text { Asynchronous estrous cycle }^{5}\end{array}$ & $\begin{array}{r}93.5(72 / 77) \\
6.5(5 / 77) \\
8.3(6 / 72)^{\mathrm{A}} \\
14.3(11 / 77)^{\mathrm{a}}\end{array}$ & $\begin{array}{r}94.9(75 / 79) \\
2.6(2 / 77) \\
1.3(1 / 75)^{\mathrm{B}} \\
3.9(3 / 77)^{\mathrm{b}}\end{array}$ & $\begin{array}{c}92.8(77 / 83) \\
3.8(3 / 80) \\
0(0 / 77)^{\mathrm{B}} \\
3.8(3 / 80)^{\mathrm{b}}\end{array}$ & $\begin{array}{l}0.82 \\
0.55 \\
0.07 \\
0.03\end{array}$ \\
\hline $\begin{array}{l}\mathrm{a}, \mathrm{b} \text { Values within rows having } \mathrm{d} \\
\mathrm{A}, \mathrm{B} \text { Values within rows with dif } \\
{ }^{1} \mathrm{Cows} \text { not observed in estrus a } \\
\mathrm{AI}\left(\mathrm{GnRH} \mathrm{d} 0, \mathrm{PGF}_{2 \alpha} \mathrm{d} 7 \text {, }\right. \\
\text { progesterone during the timed } \\
\text { ing } 1.38 \mathrm{~g} \text { of progesterone fron } \\
\text { the timed AI protocol. } \\
{ }^{2} \mathrm{P} 4=\text { progesterone concentrat } \\
{ }^{3} \mathrm{Cows} \text { that had } \mathrm{P} 4<1.0 \mathrm{ng} / \mathrm{m} \\
{ }^{4} \text { Cows that had } \mathrm{P} 4 \geq 1.0 \mathrm{ng} / \mathrm{m}\end{array}$ & $\begin{array}{l}\text { uperscript letter } \\
\text { erscripts tendec } \\
\text { resynchronizatic } \\
\text { ypionate d } 8, \text { a } \\
\text { col; CIDR } 1=1 \\
7 \text { of the timed } A \\
\text { ured in plasma. } \\
\text { er AI and } \mathrm{P} 4 \geq \\
\text { er AI and } \mathrm{P} 4<\end{array}$ & $\begin{array}{l}\text { iffer }(P<0.05 \\
\text { differ }(P=0 \text {. } \\
2 \text { injections of } \\
\text { timed AI d } 10 \\
\text { trolled interna } \\
\text { rotocol; CIDR } \\
\\
\mathrm{ng} / \mathrm{mL} 14 \mathrm{~d} \mathrm{a} \\
\mathrm{ng} / \mathrm{mL} 14 \mathrm{~d} \mathrm{a}\end{array}$ & $\begin{array}{l}4 \mathrm{~d} \text { apart) recei } \\
\text { ols. Control = } \\
\text { lease (CIDR) } \\
\text { IDR inserts fro }\end{array}$ & $\begin{array}{l}\text { d the timed } \\
\text { exogenous } \\
\text { ert contain- } \\
\text { d } 0 \text { to } 7 \text { of }\end{array}$ \\
\hline
\end{tabular}


Table 3. Effect of treatment $(\mathrm{TRT})^{1}$ on reproductive responses [\% (no./no.)] of dairy cows according to progesterone status (P4) on study d 0

\begin{tabular}{|c|c|c|c|c|c|c|c|c|c|}
\hline Response & \multicolumn{2}{|c|}{ Control } & \multicolumn{2}{|c|}{ CIDR1 } & \multicolumn{2}{|c|}{ CIDR2 } & \multicolumn{3}{|c|}{$P$-value } \\
\hline $\begin{array}{l}\text { Pregnancy/AI } \\
\text { d } 38\end{array}$ & $38.1(131 / 344)$ & $27.6(24 / 87)$ & $41.4(149 / 360)$ & $29.5(23 / 78)$ & $37.2(132 / 355)$ & $36.5(31 / 85)$ & 0.61 & 0.07 & 0.28 \\
\hline d 66 & $34.9(120 / 344)$ & $23.0(20 / 87)$ & $37.6(135 / 359)$ & $28.2(22 / 78)$ & $34.8(123 / 354)$ & $32.9(28 / 85)$ & 0.59 & 0.06 & $\begin{array}{l}0.20 \\
0.42\end{array}$ \\
\hline Pregnancy loss ${ }^{3}$ & $8.4(11 / 131)$ & $16.7(4 / 24)$ & $8.8(13 / 148)$ & $4.4(1 / 23)$ & $6.1(8 / 131)$ & $9.7(3 / 31)$ & 0.61 & 0.38 & 0.47 \\
\hline
\end{tabular}

${ }^{1}$ Cows not observed in estrus after the presynchronization (2 injections of $\mathrm{PGF}_{2 \alpha} 14 \mathrm{~d}$ apart) received the timed $\mathrm{AI}\left(\mathrm{GnRH} \mathrm{d} 0\right.$, $\mathrm{PGF}{ }_{2 \alpha} \mathrm{d} 7$, estradiol cypionate d 8, and timed AI d 10) protocols. Control = no exogenous progesterone during the timed AI protocol; CIDR $1=1$ controlled internal drug-release (CIDR) insert containing $1.38 \mathrm{~g}$ of progesterone from $\mathrm{d} 0$ to 7 of the timed AI protocol; CIDR2 $=2$ CIDR inserts from $\mathrm{d}$ 0 to 7 of the timed AI protocol.

${ }^{2} \mathrm{HP}=$ cows with plasma progesterone $\geq 1 \mathrm{ng} / \mathrm{mL}$ on the day of the GnRH of the timed AI protocol (study d 0); LP = cows with plasma progesterone $<1 \mathrm{ng} / \mathrm{mL}$ on the day of the $\mathrm{GnRH}$ of the timed $\mathrm{AI}$ protocol.

${ }^{3}$ Pregnancy loss between 38 and $66 \mathrm{~d}$ of gestation. One cow from CIDR 1 and 1 from CIDR 2 were sold before pregnancy reconfirmation on d 66 after AI.

BCS did not affect risk of pregnancy loss between 38 and $66 \mathrm{~d}$ of gestation. Furthermore, no interaction between treatment and progesterone concentration on $\mathrm{d} 0$ or BCS was observed for the risk of pregnancy loss.

\section{DISCUSSION}

Intravaginal inserts containing progesterone have been used to improve synchrony of estrus and ovulation (Carrick and Shelton, 1967; Scanlon et al., 1972) and to promote resumption of postpartum ovulation in dairy cattle (Chebel et al., 2006; Cerri et al., 2009). Their use has been recommended in TAI protocols, particularly in anovular cows to improve P/AI (Stevenson et al., 2006).

The proportion of LP cows on the first day of the TAI protocol was approximately $20 \%$. Because anovular cows are less likely to be in estrus after treatment with $\mathrm{PGF}_{2 \alpha}$ than cyclic cows (Chebel et al., 2006), it was initially thought that an increased proportion of cows submitted to the TAI protocols would be anovular. Although this study did not evaluate the prevalence of anovular cows from those inseminated after estrus, it seems that inseminating cows after the second $\mathrm{PGF}_{2 \alpha}$ of the presynchronization protocol and removing them from the study population did not substantially alter the prevalence of anovular cows when compared with studies in which all cows were subjected to a TAI protocol at similar DIM (Moreira et al., 2001; Cerri et al., 2004). In those reports, the proportion of anovular cows at the beginning of TAI protocol ranged from 20 to $40 \%$.

It has been demonstrated that treatment of cyclic lactating dairy cows without a CL with a single CIDR results in average concentration of progesterone between 0.65 and $0.80 \mathrm{ng} / \mathrm{mL}$ during a 7 -d treatment (Cerri et al., 2009). Compared with control cows, treatment with
1 or 2 CIDR inserts increased progesterone concentrations during the TAI protocol by 0.86 and $1.76 \mathrm{ng} /$ $\mathrm{mL}$, respectively. The greater increase in progesterone concentration resulting from CIDR treatment observed in the present study compared with previous studies (Cerri et al., 2009) is likely the result of contributions from endogenous progesterone from the CL. Because the response was linear with number of CIDR inserts and no interaction between treatment and day was observed for concentrations of progesterone, it can be concluded that treatment was efficacious in supplementing progesterone resulting in a dose-dependent response in plasma concentrations.

The average progesterone concentration between 7 and $14 \mathrm{~d}$ after AI did not differ among treatments. It has recently been demonstrated that progesterone concentration 11 to $14 \mathrm{~d}$ after AI was greater for cows receiving a single CIDR insert during TAI protocols (Melendez et al., 2006; Chebel et al., 2008). Chebel et al. (2008) demonstrated that the increase in progesterone concentration in CIDR-treated cows was a consequence of improved synchrony of ovulation following insemination, because a greater proportion of CIDR-treated cows had progesterone concentration $\geq 1.0 \mathrm{ng} / \mathrm{mL}$ at 11 to $14 \mathrm{~d}$ after AI. It is unclear why progesterone concentrations 7 and $14 \mathrm{~d}$ after AI were not affected by CIDR treatment in the present study, even though cows that received 1 or 2 CIDR inserts were less likely to have an asynchronous estrous cycle following TAI.

Cows treated with CIDR inserts during the TAI protocol tended to be less likely to experience premature luteolysis in the current study. Cerri et al. (2009) observed that anovular cows treated with CIDR inserts during the presynchronization were less likely to be reinseminated within 6 to $17 \mathrm{~d}$ after timed AI, which suggests a reduced incidence of premature luteolysis and short luteal phases in CIDR-treated cows. The 
lack of progesterone exposure before ovulation and AI results in premature upregulation of estradiol and oxytocin receptors in the endometrium, resulting in premature $\mathrm{PGF}_{2 \alpha}$ secretion and luteolysis (Inskeep, 2004). Although treatment did not alter the proportion of cows that experienced delayed ovulation, treatment with CIDR inserts reduced asynchrony of estrous cycle after the TAI protocol. The concentrations of progesterone resulting from treatment with CIDR inserts are capable of inhibiting estrus and ovulation in the event that luteolysis occurred during treatment (Chenault et al., 2003; El-Zarkouny and Stevenson, 2004), which results in tighter synchrony of estrus and ovulation after the removal of the insert (Lucy et al., 2001; Chebel et al., 2006).

Treatment of lactating dairy cows with 1 or 2 CIDR inserts during the TAI protocol did not improve P/AI at $38 \pm 3$ and at $66 \pm 3 \mathrm{~d}$ after insemination. Likewise, treatment with CIDR did not reduce the incidence of pregnancy loss. Incorporation of a CIDR insert to TAI protocols such as the Ovsynch or Heatsynch has not consistently influenced fertility of high-producing lactating dairy cows. El-Zarkouny et al. (2004) reported improvements in $\mathrm{P} / \mathrm{AI}$ in only 1 of 2 experiments in which the CIDR was inserted during the Ovsynch protocol. In the experiment with the larger number of experimental units, CIDR treatment had no effect on $\mathrm{P} / \mathrm{AI}$ regardless of whether cows were or were not presynchronized with $\mathrm{PGF}_{2 \alpha}$ (El-Zarkouny et al., 2004). Similarly, cows submitted to a $\mathrm{PGF}_{2 \alpha}$-based presynchronization protocol and then to a TAI protocol plus a CIDR insert had similar P/AI compared with cows that did not receive a CIDR insert (Galvão et al., 2004). On the other hand, Stevenson et al. (2006) observed that nonpresynchronized cows that received a CIDR insert during the Ovsynch protocol had greater $\mathrm{P} / \mathrm{AI}$ at $28 \mathrm{~d}$ after AI compared with those that did not receive a CIDR insert, but the positive effect of supplemental progesterone on $\mathrm{P} / \mathrm{AI}$ at $56 \mathrm{~d}$ after TAI was dependent on herd. It is important to note that all cows were submitted to the timed AI protocol in the studies referenced above, and not inseminated if observed in estrus before the TAI, even when presynchronization was performed. In recent studies in which only cows not observed in estrus following presynchronization with $\mathrm{PGF}_{2 \alpha}$ were submitted to TAI protocols, CIDR treatment during the TAI protocol increased P/ AI (Melendez et al., 2006; Chebel et al., 2008). Contrary to the initial hypothesis of the current study, the effect of progesterone supplementation on fertility was not observed in anestrous cows (Chebel et al., 2008). It is most likely that the benefits from CIDR treatment are related to improved synchronization of the estrous cycle when cows not previously observed in estrus are submitted to TAI protocols (Chebel et al., 2008).

It is unclear, however, why the effects of CIDR treatment during TAI protocols on $\mathrm{P} / \mathrm{AI}$ are inconsistent. It is possible that improvements are observed when the ovulatory stimulus is GnRH (Melendez et al., 2006; Chebel et al., 2008) and not estradiol cypionate as in the present study and also observed by others (Galvão et al., 2004). When cows received estradiol cypionate to induce ovulation, approximately 20 and $50 \%$ of them were observed in estrus 24 and $48 \mathrm{~h}$ after estradiol, respectively (Cerri et al., 2004; Galvão et al., 2004). Because cows in estrus before the scheduled TAI are typically inseminated, the benefits of CIDR on synchronization of ovulation might be reduced when estradiol cypionate rather than $\mathrm{GnRH}$ is used as the ovulatory stimulus. It was initially thought that the amount of progesterone would also be important to fertility, particularly in LP cows. Nevertheless, no interaction between treatment and ovarian status on d 0 (LP and $\mathrm{HP}$ ) was observed for P/AI either at $38 \pm 3$ or $66 \pm 3 \mathrm{~d}$ after TAI. These data imply that neither supplemental progesterone nor the amount of supplemental progesterone benefited the fertility of LP cows subjected to the TAI protocol. Also, it is possible that the increments in progesterone concentrations observed with 1 or 2 CIDR, approximately $0.9 \mathrm{ng} / \mathrm{mL}$ per CIDR, were not adequate to improve fertility of high-producing, lactating dairy cows. Therefore, it is plausible to suggest that LP cows might require increases in progesterone concentration that are greater than $1.8 \mathrm{ng} / \mathrm{mL}$ when exogenous progesterone is supplemented to have $\mathrm{P} / \mathrm{AI}$ similar to that of HP cows. For this to be achieved, either a different supplemental strategy or additional CIDR need to be investigated.

Although previous studies demonstrated that insertion of a CIDR on the day of the first GnRH injection of the TAI protocol reduced the proportion of cows ovulating in response to GnRH (Galvão et al., 2004; Stevenson et al., 2008), in the present study treatment with CIDR inserts had no effect on ovulation in response to the GnRH injection. Because the sample size for the study was based on expected differences in $\mathrm{P} / \mathrm{AI}$, and not on ovulatory response to $\mathrm{GnRH}$, the number of cows evaluated for ovulation (77 to 83 cows per treatment) might have not been sufficient to detect statistical differences. Nonetheless, as demonstrated by other studies (Galvão et al., 2004; Stevenson et al., 2008), cows treated with 1 CIDR insert were less likely to have a CL and had fewer CL on the day of the $\mathrm{PGF}_{2 \alpha}$ injection of the TAI protocol. Interestingly, however, on the day of $\mathrm{PGF}_{2 \alpha}$ injection of the TAI protocol, CIDR2 cows were as likely as control cows to have a CL 
and had a similar number of CL compared with control cows, which suggest that if the CIDR indeed reduces ovulation, it is unlikely that this effect is mediated by increased progesterone concentrations.

Control and CIDR1 cows that did not ovulate in response to the GnRH injection had larger follicles on the day of the $\mathrm{PGF}_{2 \alpha}$ injection of the TAI protocol compared with those that ovulated, but ovulation in response to the $\mathrm{GnRH}$ injection did not affect the size of the largest follicle on the day of the $\mathrm{PGF}_{2 \alpha}$ injection among CIDR2 cows. Because CIDR2 cows had increased concentrations of progesterone during the TAI protocol, it plausible to suggest that it might have reduced LH pulsatility, which would decrease the rate of follicle growth after deviation (Calder et al., 1999; Nation et al., 2000).

\section{CONCLUSIONS}

Supplementing lactating dairy cows not previously observed in estrus with increasing amounts of progesterone via CIDR increased concentrations of progesterone linearly with the number of inserts used during the TAI protocol, and the average increment was approximately $0.9 \mathrm{ng} / \mathrm{mL}$ per CIDR. Treatment with 1 or 2 CIDR during the TAI protocol reduced estrous cycle asynchrony following insemination but did not influence progesterone concentrations in the postinsemination period. Despite the linear increase in progesterone concentrations during the TAI protocol in cows receiving CIDR, supplemental progesterone in cows not previously observed in estrus after $\mathrm{PGF}_{2 \alpha}$ did not improve pregnancy per AI or maintenance of pregnancy in the first $66 \mathrm{~d}$ of gestation. These results indicate that supplementation with increasing amounts of progesterone to result in an additional 0.9 to 1.8 $\mathrm{ng} / \mathrm{mL}$ more progesterone in plasma during a TAI protocol that used estradiol cypionate to induce ovulation does not benefit fertility of lactating dairy cows not previously observed in estrus. They also suggest that inconsistency in fertility responses to treatment of high-producing dairy cows with progesterone via CIDR does not seem to be related to the amount of progesterone supplemented when plasma concentrations increase up to $1.8 \mathrm{ng} / \mathrm{mL}$ during the timed AI protocol. Either more CIDR inserts need to be used or an alternative strategy is required to evaluate the effect of increasing progesterone on fertility of high-producing, lactating dairy cows.

\section{REFERENCES}

Calder, M. D., B. E. Salfen, B. Bao, R. S. Youngquist, and H. A. Garverick. 1999. Administration of progesterone to cows with ovarian follicle cysts results in a reduction in mean $\mathrm{LH}$ and $\mathrm{LH}$ pulse frequency and initiates ovulatory follicular growth. J. Anim. Sci. 77:3037-3042.

Caraviello, D. Z., K. A. Weigel, P. M. Fricke, M. C. Wiltbank, M. J. Florent, N. B. Cook, K. V. Nordlund, N. R. Zwald, and C. L. Rawson. 2006. Survey of management practices on reproductive performance of dairy cattle on large US commercial farms. J. Dairy Sci. 89:4723-4735.

Carrick, M. J., and J. N. Shelton. 1967. The synchronization of oestrus in cattle with progestagen-impregnated intravaginal sponges. J. Reprod. Fertil. 14:21-32.

Cerri, R. L. A., H. M. Rutigliano, R. G. S. Bruno, and J. E. P. Santos. 2009. Progesterone concentration, follicular development and induction of cyclicity in dairy cows receiving intravaginal progesterone inserts. Anim. Reprod. Sci. 110:56-70.

Cerri, R. L. A., J. E. P. Santos, S. O. Juchem, K. N. Galvão, and R. C. Chebel. 2004. Timed artificial insemination with estradiol cypionate or insemination at estrus in high-producing dairy cows. J. Dairy Sci. 87:3704-3715.

Chebel, R. C., M. J. Al-Hassan, P. M. Fricke, J. E. Santos, C. A Martel, J. S. Stevenson, R. Garcia, R. L. Ax, and F. Moreira. 2008. Supplementation of progesterone via CIDR inserts during ovulation synchronization protocols in lactating dairy cows. J. Dairy Sci. 91(Suppl. 1):257. (Abstr.)

Chebel, R. C., J. E. P. Santos, R. L. A. Cerri, H. M. Rutigliano, and R. G. S. Bruno. 2006. Reproduction in dairy cows following progesterone insert presynchronization and resynchronization protocols. J. Dairy Sci. 89:4205-4219.

Chenault, J. R., J. F. Boucher, K. J. Dame, J. A. Meyer, and S. L. Wood-Follis. 2003. Intravaginal progesterone insert to synchronize return to estrus of previously inseminated dairy cows. J. Dairy Sci. 86:2039-2049.

El-Zarkouny, S. Z., J. A. Cartmill, B. A. Hensley, and J. S. Stevenson. 2004. Pregnancy in dairy cows after synchronized ovulation regimens with or without presynchronization and progesterone. J. Dairy Sci. 87:1024-1037.

El-Zarkouny, S. Z., and J. S. Stevenson. 2004. Resynchronizing estrus with progesterone or progesterone plus estrogen in cows of unknown pregnancy status. J. Dairy Sci. 87:3306-3321.

Ferguson, J. D., D. T. Galligan, and N. Thomsen. 1994. Principal descriptors of body condition score in Holstein cows. J. Dairy Sci. 77:2695-2703.

Folman, Y., M. Kaim, Z. Herz, and M. Rosenberg. 1990. Comparison of methods for the synchronization of estrous cycles in dairy cows. 2. Effects of progesterone and parity on conception. J. Dairy Sci. 73:2817-2825.

Galvão, K. N., J. E. P. Santos, S. O. Juchem, R. L. A. Cerri, A. C. Coscioni, and M. Villaseñor. 2004. Effect of addition of a progesterone intravaginal insert to a timed insemination protocol using estradiol cypionate on ovulation rate, pregnancy rate, and late embryonic loss in lactating dairy cows. J. Dairy Sci. 87:35083517.

Gümen, A., and M. C. Wiltbank. 2005. Length of progesterone exposure needed to resolve large follicle anovular condition in dairy cows. Theriogenology 63:202-218.

Inskeep, E. K. 2004. Preovulatory, postovulatory, and postmaternal recognition effects of concentrations of progesterone on embryonic survival in the cow. J. Anim. Sci. 82(E. Suppl.):E24-E39.

Lucy, M. C., H. J. Billings, W. R. Butler, L. R. Ehnis, M. J. Fields, D. J. Kesler, J. E. Kinder, R. C. Mattos, R. E. Short, W. W. Thatcher, R. P. Wettemann, J. V. Yelich, and H. D. Hafs. 2001. Efficacy of an intravaginal progesterone insert and an injection of $\mathrm{PGF}_{2 \mathrm{a}}$ for synchronizing estrus and shortening the interval to pregnancy in postpartum beef cows, peripubertal beef heifers, and dairy heifers. J. Anim. Sci. 79:982-995.

Melendez, P., G. Gonzalez, E. Aguilar, O. Loera, C. Risco, and L. F. Archbald. 2006. Comparison of two estrus-synchronization protocols and timed artificial insemination in dairy cattle. J. Dairy Sci. 89:4567-4572.

Moreira, F., C. Orlandi, C. A. Risco, R. Mattos, F. Lopes, and W. W. Thatcher. 2001. Effects of presynchronization and bovine 
somatotropin on pregnancy rates to a timed artificial insemination protocol in lactating dairy cows. J. Dairy Sci. 84:1646-1659.

Nation, D. P., C. R. Burke, G. Parton, R. Stevenson, and K. L. Macmillan. 2000. Hormonal and ovarian responses to a 5-day progesterone treatment in anoestrous dairy cows in the third week post-partum. Anim. Reprod. Sci. 63:13-25.

Santos, J. E. P., H. M. Rutigliano, and M. F. Sá Filho. 2009. Risk factors for resumption of postpartum cyclicity and embryonic survival in lactating dairy cows. Anim. Reprod. Sci. 110:207221

Santos, J. E. P., W. W. Thatcher, R. C. Chebel, R. L. A. Cerri, and K. N. Galvão. 2004. The effect of embryonic death rates in cattle on the efficacy of estrus synchronization programs. Anim. Reprod. Sci. 82-83:513-535.

Scanlon, P. F., J. Sreenan, and I. Gordon. 1972. Synchronization of oestrus in heifers by intravaginal application of progesterone. Vet. Rec. 90:440-441.
Stevenson, J. S., J. R. Pursley, H. A. Garverick, P. M. Fricke, D J. Kesler, J. S. Ottobre, and M. C. Wiltbank. 2006. Treatment of cycling and noncycling lactating dairy cows with progesterone during Ovsynch. J. Dairy Sci. 89:2567-2578.

Stevenson, J. S., D. E. Tenhouse, R. L. Krisher, G. C. Lamb, J. E. Larson, C. R. Dahlen, J. R. Pursley, N. M. Bello, P. M. Fricke, M. C. Wiltbank, D. J. Brusveen, M. Burkhart, R. S. Youngquist, and H. A. Garverick. 2008. Detection of anovulation by heatmount detectors and transrectal ultrasonography before treatment with progesterone in a timed insemination protocol. J. Dairy Sci. 91:2901-2915.

Zollers, W. G. Jr., H. A. Garverick, M. F. Smith, R. J. Moffatt, B. E. Salfen, and R. S. Youngquist. 1993. Concentrations of progesterone and oxytocin receptors in endometrium of postpartum cows expected to have a short or normal oestrous cycle. J. Reprod. Fertil. 97:329-337. 